\begin{tabular}{|l|l|}
\hline JAN 81999 & Page 1 of $\frac{1}{1}$ \\
\hline
\end{tabular}

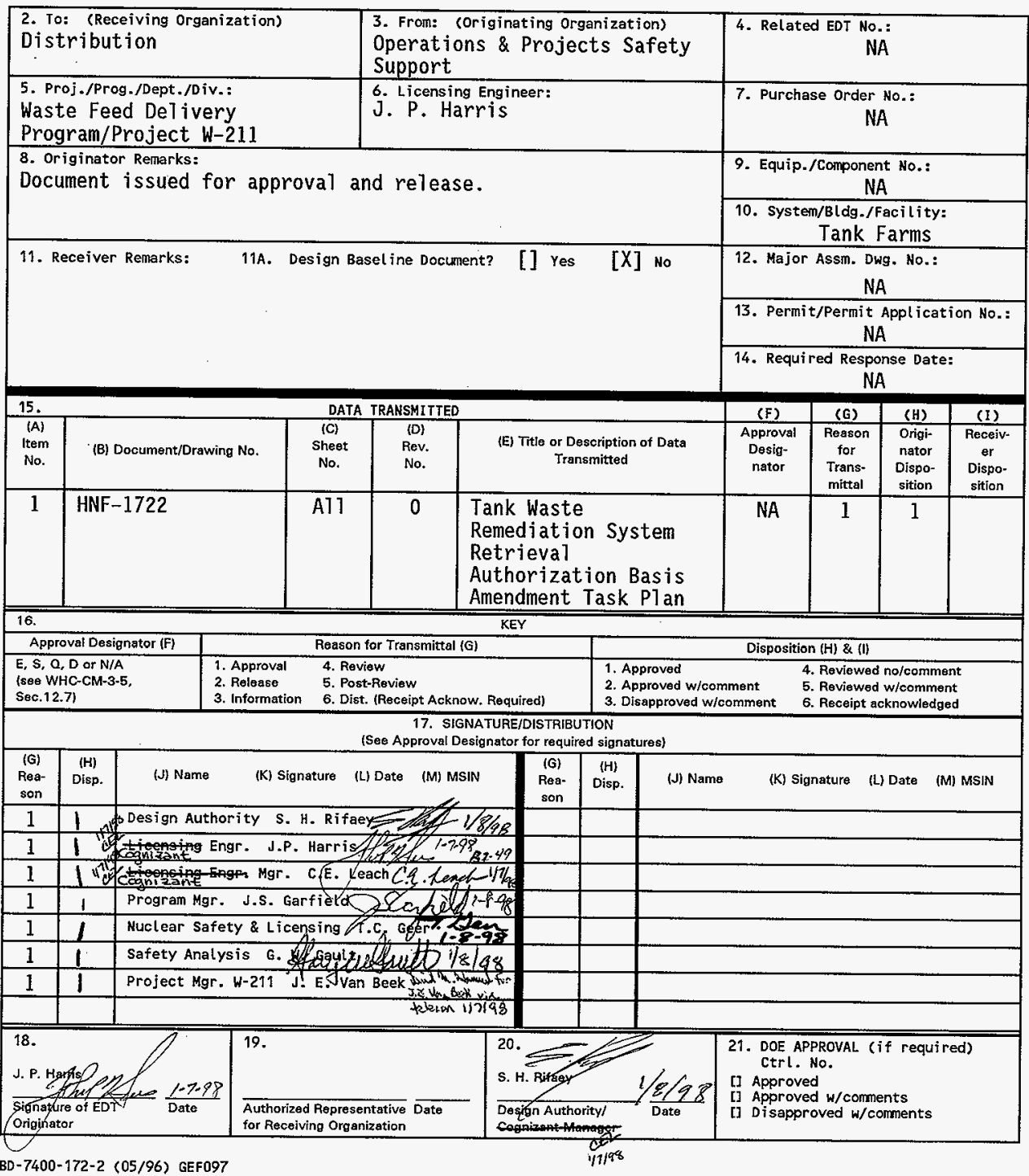


HNF-1722, Rev. 0

\section{Tank Waste Remediation System Retrieval Authorization Basis Amendment Task Plan}

\section{T. G. Goetz}

Lockheed Martin Hanford Company, Richland, WA 99352

U.S. Department of Energy Contract DE-AC06-96RL13200.

$\begin{array}{lll}\text { EDT/ECN: } & 622842 & \text { UC: } 2030 \\ \text { Org Code: } & 2 N 140 & \text { Charge Code: } \\ \text { B\&R Code: } & \text { EW3130010 } & \text { Tota1 Pages: } 40\end{array}$

Key Words: Authorization Basis, TWRS, Waste Feed Delivery, W-211

Abstract: This task $p l a n$ is a documented agreement between Nuclear Safety and Licensing and the Process Development group within the Waste Feed Delivery organization. The purpose of this task $p l a n$ is to identify the scope of work, tasks and deliverables, responsibilities, manpower, and schedules associated with an authorization basis amendment as a result of the Waste Feed Waste Delivery Program, Project W-211, and Project $W-T B D$ :

TRADEMARK DISCLAIMER. Reference herein to any specific comercial product, process, or service by trade name, trademark, manufacturer, or otherwise, does not necessarily constitute or imply its endorsement, recomendation, or favoring by the United States Government or any agency thereof or its contractors or subcontractors.

Printed in the United States of America. To obtain copies of this document, contact: WHC/BCS Document Control Services, P.O. BoX 1970, Mailstop H6-08, Richland WA 99352, Phone (509) 372-2420; Fax (509) 376.4989.
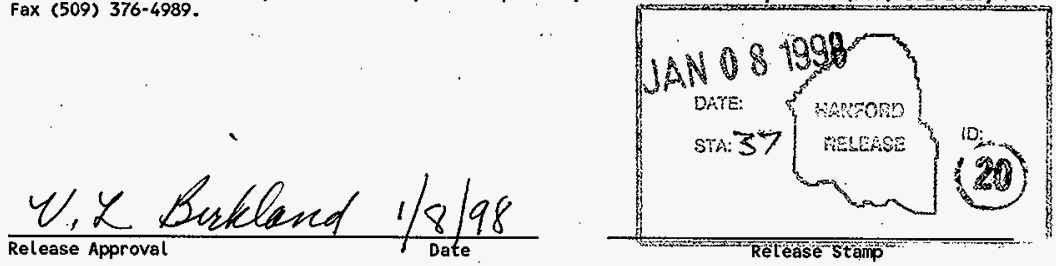
LEGAL DISCLAIMER

This report was prepared as an account of work sponsored by an agency of the United States Government. Neither the United States Government nor any agency thereof, nor any of their employees, nor any of their contractors, subcontractors or their employees, makes any warranty, express or implied, or assumes any legal liability or responsibility for the accuracy, completeness, or any third party's use or the results of such use of any information, apparatus, product, or process disclosed, or represents that its use would not infringe privately owned rights.

Reference herein to any specific commercial product, process, or service by trade name, trademark. manufacturer, or otherwise, does not necessarily constitute or imply its endorsement, recommendation, or favoring by the United States Government or any agency thereof or its contractors or subcontractors. The views and opinions of authors expressed herein do not necessarily state or reflect those of the United States Government or any agency

thereof.

This report has been reproduced from the best available copy.

Available in paper copy and microfiche.

Available to the U.S. Department of Energy

and its contractors from

U.S. Department of Energy

Office of Scientific and Technical Information (OSTI)

P.O. Box 62

Oak Ridge. TN 37831

(615) $576-8401$

Available to the public from the U.S. Department of Commerce

National Technical Information Service (NTIS)

5285 Port Royal Road

Springfield, VA 22161

(703) 487-4850

Printed in the United States of America

DISCLM-1.CHP (8-95) 


\section{Tank Waste Remediation System Retrieval Authorization Basis Amendment Task Plan}

T. G. Goetz

D. M. Hammond

DE\&S Hanford, Inc.

J. P. Harris III

Numatec Hanford Corporation

Date Published

January 1998

Prepared by Lockheed Martin Hanford Corporation Richland, Washington

Prepared for the U.S. Department of Energy

Fluor Daniel Hanford, Inc. 
HNF-1722 Rev 0

This page intentionally left blank. 
Document Title: Tank Waste Remediation System Retrieval Authorization Basis Amendment Task Plan

Approved by:
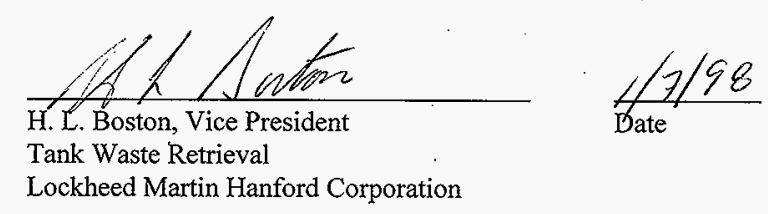

Tank Waste Retrieval

Date

Lockheed Martin Hanford Corporation 
HNF-1722 Rev 0

This page intentionally left blank. 


\section{HNF-1722 Rev 0}

\section{FOREWORD}

This task plan is a documented agreement between Nuclear Safety and Licensing and the Process Development group within the Waste Feed Delivery organization. The purpose of this task plan is to identify the scope of work, tasks and deliverables, responsibilities, manpower, and schedules associated with the requirement for an Authorization Basis amendment as a result of the Waste Feed Delivery program, Project W-211, and Project "W-TBD". This task plan is an internal working-level, "living" document required by HNF-IP-0842, TWRS Administration, Volume IV, "Engineering," Section 5.10, "Authorization Basis Amendments and Annual Updates" (LMHC 1997). This task plan does not include a detailed scope of work, tasks and deliverables, responsibilities, manpower, and schedules for Projects $W-314, W-454, W-464, W-465$, $W-519$ and W-520. The details for these projects are provided in the task plans for each project, as necessary, as required by LMHC (1997). These projects are only addressed in this task plan as necessary to demonstrate the relationship between these projects and the projects included within this task plan.

This task plan represents only one of the deliverables provided by Nuclear Safety and Licensing to support the Readiness To Proceed effort and is therefore, not intended to represent a complete description of all activities performed. Nuclear Safety and Licensing also provided an Execution Plan, Technical Basis Review (TBR) risk assessment tables, and TBRs and associated resource loaded schedules for Level I Logic Activities 620.030,620.050,150.B10,150.B14, 150.B16, 150.B17, 440.120,460.085, and 460.130 (only the first six identify activities within the scope of this task plan). These 


\section{HNF-1722 Rev 0}

other sources provide information on organization mission; objectives; work activities supporting Retrieval, Waste Feed Delivery, and Waste Receipt; execution strategy; risks; enabling assumptions; and mitigation plans. Thus, this task plan (which is a continuation of activities as required by procedure), in conjunction with other deliverables provided, demonstrates the Readiness To Proceed of Nuclear Safety and Licensing. Appendix B identifies the guidance and requirements satisfied by this task plan.

Figure F-1 demonstrates the recent development of allowable operations for the Tank Waste Remediation System (TWRS) and the expected development of allowable operations in order to support Retrieval, Waste Feed Delivery, and Waste Receipt. As previously stated, the only activities identified in Figure F-1 that are within the scope of this task plan are the Waste Feed Delivery program, Project W-211, and Project "W-TBD". It should be noted that projects may or may not change the Authorization Basis for TWRS. 
HNF-1722 Rev 0

Figủe F-1. Allowable Operations.

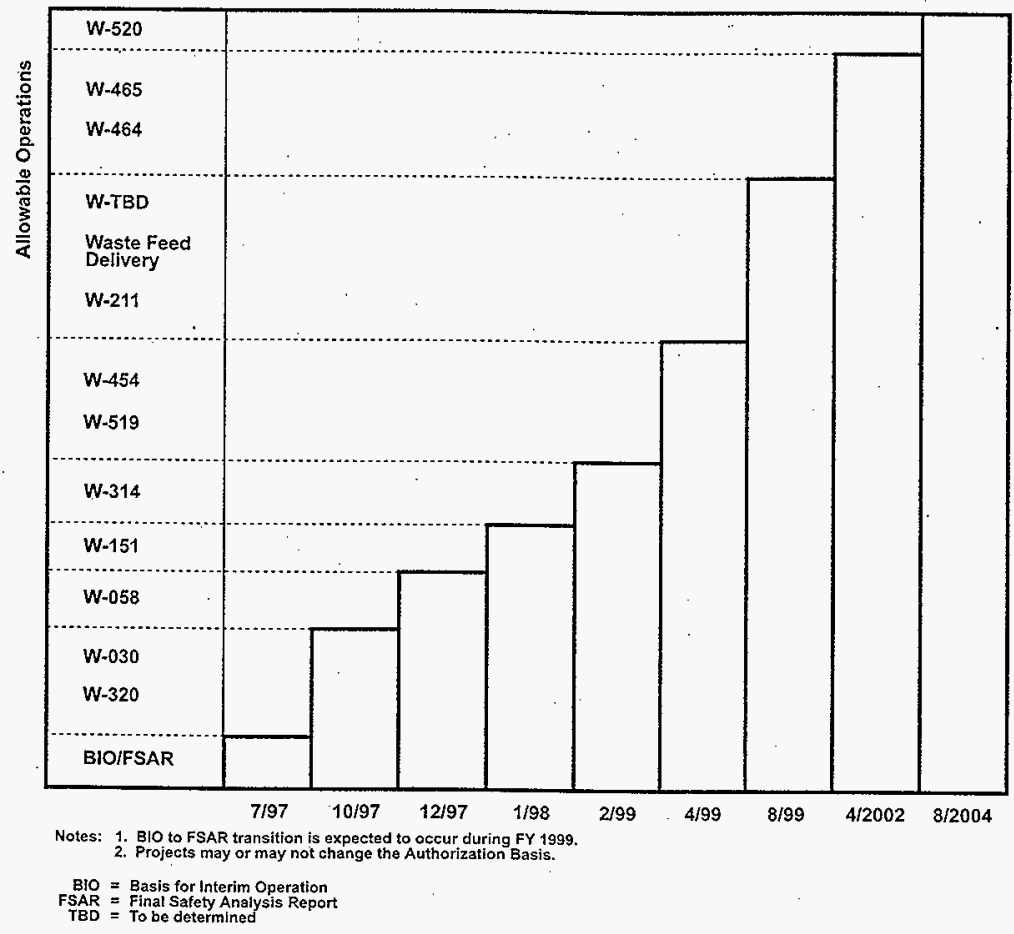

HG97110249.52 $1722-F 1$ 
HNF-1722 Rev 0

This page intentionally left blank. 
HNF-1722 Rev 0

\section{CONTENTS}

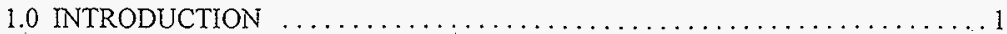

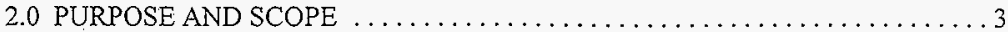

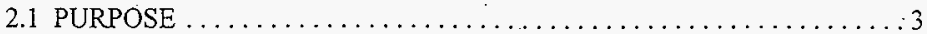

2.2 SCOPE OF AUTHORIZATION BASIS AMENDMENT $\ldots \ldots \ldots \ldots \ldots 4$

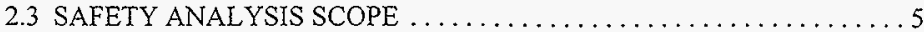

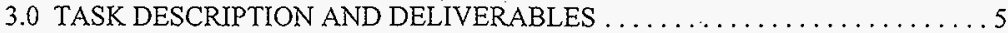

3.1 U.S. DEPARTMENT OF ENERGY ORDERS, STANDARDS, AND

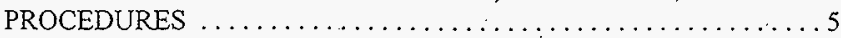

3.2 SAFETY ANALYSIS ASSUMPTIONS AND PARAMETERS $\ldots \ldots \ldots .7$

3.3 TASK AND DELIVERABLE DESCRIPTIONS . . . . . . . . . . 8

4.0 RESPONSIBILITIES AND STAFFING REQUIREMENTS $\ldots \ldots \ldots \ldots \ldots 15$

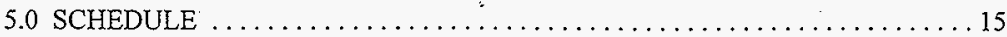

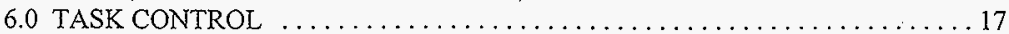

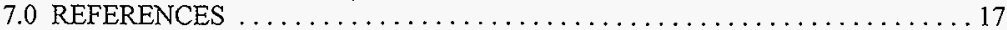

APPENDICES

A WASTE FEED DELIVERY AUTHORIZATION BASIS ASSESSMENT LICENSING STRATEGY EVALUATION TOPICS . . . . . . . . . . . A-i

B - GUIDANCE AND REQUIREMENTS TO DELIVERABLES

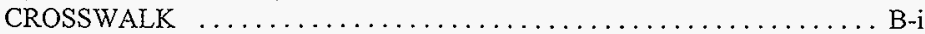




\section{LIST OF FIGURES}

1. Overview of Retrieval Licensing Strategy $\ldots \ldots \ldots \ldots \ldots \ldots \ldots \ldots \ldots \ldots \ldots \ldots \ldots$

2. Task Plan Development Flow Chart $\ldots \ldots \ldots \ldots \ldots \ldots \ldots \ldots \ldots \ldots$

\section{LIST OF TABLES}

1. Schedule for Waste Feed Delivery Authorization Basis Amendment $\ldots \ldots \ldots \ldots 15$

\section{LIST OF TERMS}

$\begin{array}{ll}\text { BIO } & \text { Basis for Interim Operation } \\ \text { DOE } & \text { U.S. Department of Energy } \\ \text { DST } & \text { double-shell tank } \\ \text { ECN } & \text { Engineering Change Notice } \\ \text { FDH } & \text { Fluor Daniel Hanford, Inc. } \\ \text { FSAR } & \text { Final Safety Analysis Report } \\ \text { HAZOP } & \text { hazard and operability } \\ \text { HLW } & \text { high-level waste } \\ \text { LAW } & \text { low-activity waste } \\ \text { LMHC } & \text { Lockheed Martin Hanford Corporation } \\ \text { PHMC } & \text { Project Hanford Management Contract } \\ \text { RL } & \text { U.S. Department of Energy, Richland Operations Office } \\ \text { SAR } & \text { Safety Analysis Report } \\ \text { S/RID } & \text { Standards/Requirements Identification Document } \\ \text { TSR } & \text { Technical Safety Requirements } \\ \text { TWRS } & \text { Tank Waste Remediation System } \\ \text { USQ } & \text { Unreviewed Safety Question } \\ \text { WFD } & \text { Waste Feed Delivery }\end{array}$




\section{TANK WASTE REMEDIATION SYSTEM RETRIEVAL AUTHORIZATION BASIS AMENDMENT TASK PLAN}

\subsection{INTRODUCTION}

Waste Feed Delivery (WFD) is a modified mission that involves the retrieval of both high-level waste (HLW) and low-activity waste (LAW) from double-shell tanks (DST) with subsequent transfer to the private contractor(s) for vitrification, followed by return of the vitrified products to the Tank Waste Remediation System (TWRS) for disposal. Phase $1 \mathrm{~B}$ is the first portion of the overall WFD campaign and involves retrieval from selected DSTs between the years 2002 and 2011. This mission will require installation of new equipment and performance of retrieval operations that have not previously been performed at the Hanford site. A necessary prerequisite to the actual retrieval and delivery of waste is ensuring that the TWRS Authorization Basis envelops the proposed activities.

The two major projects that support WFD are Projects W-211, Initial Tank Retrieval System, and W-314, Tank Farms Restoration and Safe Operation. Under Project W-211, mixer pumps and transfer pumps will be installed in the two feed staging tanks (tanks AP-102 and AP-104, which will send LAW to the private contractor) and the first eight DSTs from which waste will be retrieved. In addition, a new valve pit will be installed in the AP tank farm to allow transfer of HLW to the private contractor. Project W-314, addressed in a previous task plan, complements Project W-211 by installing new transfer lines, upgrading the valve/pump pits, and making other improvements to facilitate transfer of the waste to the private contractor. Several other projects (i.e., Projects W-454, AW Jumper Manifold Upgrade, and W-519, Privatization Infrastructure Project, neither of which warrants task plan documents since the impact on the Authorization Basis is minimal) will also support WFD. For the Disposal Mission, the three major projects are W-464, Solidified HLW Interim Storage (Canister Storage Building Facility Modifications), W-465, Immobilized Low-Level Waste Interim Storage, and W-520, New LAW Disposal Vaults. A separate task plan will be prepared for each of the disposal projects.

It is important to note that it is within the scope of each of the aforementioned projects to evaluate the project-specific activities against the Authorization Basis and to make the necessary modifications to ensure the activities are enveloped by the Authorization Basis. The scope of this task plan is to evaluate the integrated process of WFD and modify the Authorization Basis as necessary to envelop the activities (taking advantage of the fact that some of this work will be done by the projects). It is recognized that additional work scope, such as follow-on to Project W-151, Tank AZ-101 Mixer Pump Test, and follow-on to Project W-211, collectively referred to as "W-TBD," 
may be undertaken during the preparation for WFD. When sufficiently defined, these projects will also be factored into the Licensing Strategy, as delineated by this Task Plan. The relationship between this task plan and all projects and activities which comprise the Retrieval Mission is shown in Figure 1.

Figure 1. Overview of Retrieval Licensing Strategy.

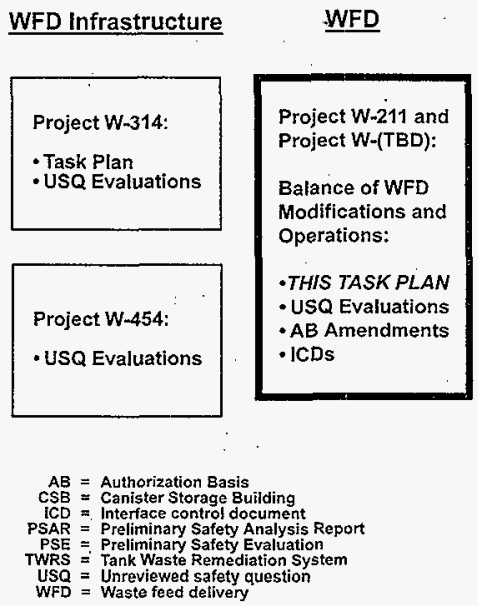

\section{Privatization Infrastructure \\ Receipt of Treated Waste}
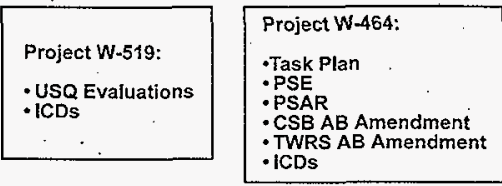

Project W-465:

-Task Plan

- PSE

- PSAR

- TWRS AB Addition

- ICDs

Project W-520:

-Task Plan

- PSE

- PSAR

- TWRS AB Addition

-ICDs

Note: This task plan addresses the WFD portion of the retrieval licensing strategy.

HG97110249.13

The first step in determining the adequacy of the Authorization Basis documentation is to evaluate the proposed WFD activities against the current Authorization Basis via the Unreviewed Safety Question (USQ) process.

Because the current TWRS Authorization Basis (i.e., HNF-SD-WM-BIO-001, Tank Waste Remediation System Basis for Interim Operation [BIO] [FDH 1997]) was written for the storage mission only, some positive USQ screenings (and subsequent positive USQ determinations) are anticipated. To reconcile these positive USQ determinations with the Authorization Basis, the following activities will be performed.

1. Perform a hazard and operability (HAZOP) study following the methodology. outlined in Section 5.2 of the BIO (FDH 1997) and approved procedures to analyze the WFD activities identified as outside the scope of the current Authorization Basis. 
2. Analyze the new accidents or reanalyze the existing BIO (FDH 1997) accidents based on the new WFD parameters (i.e., inputs into frequency or consequence calculations that are expected to increase the original BIO results). Based on the analyses results, identify safety-class and safety-significant systems, structures, and components. As an alternative, planned operations may be changed to reduce the consequences to acceptable levels.

3. Modify the technical safety requirements (TSRs) based on the revised accident analysis results.

4. Revise and/or develop new procedures to implement the modified TSRs.

5. Incorporate the revised HAZOP and control identification results in the hazard analysis database.

Those accidents identified for WFD that are adequately covered in the BIO (FDH 1997) will not be reanalyzed, but the adequacy of coverage of these accidents in the BIO will be discussed in the supporting safety analysis documentation. Accidents similar to those analyzed in the BIO, but not bounded by the BIO (because of differences in key parameters), will be reanalyzed and documented in the Authorization Basis amendment package. New accidents will be identified and analyzed as needed.

\subsection{PURPOSE AND SCOPE}

\subsection{PURPOSE}

This document establishes the plan to amend the Authorization Basis so that it encompasses WFD Phase 1B activities. Because of the breadth and duration of WFD activities, adequate technical information on some activities may not be available for inclusion in the initial amendment to the Authorization Basis that is described in this task plan. Therefore, the intent is to capture the best available information (particularly on the first tanks to be retrieved) and prepare the Authorization Basis amendment package accordingly with the acknowledgment that future amendments will almost certainly be required as additional technical information becomes available. 


\subsection{SCOPE OF AUTHORIZATION BASIS AMENDMENT}

Because of the size of the WFD mission, the Authorization Basis amendment will encompass new activities, including the installation of new equipment by multiple ongoing projects and the performance of new operations. A listing of the WFD Authorization Basis Assessment Licensing Strategy Evaluation Topics is provided in Appendix A. This list identifies the topics currently being evaluated to determine which aspects of the WFD process are outside the current TWRS Authorization Basis. This list will be updated as additional information is provided for evaluation of impact on the TWRS Authorization Basis.

A key assumption has been made that the two tanks to be turned over to the private contractor (i.e., tanks AP-106 and AP-108, which will receive LAW from tanks AP-102 and AP-104) will have a separate Authorization Basis and, therefore, are outside the scope of this task plan. It is assumed that the private contractor will develop and maintain the Authorization Basis for these two tanks. However, the removal of tanks AP-106 and AP-108 from the TWRS Authorization Basis, upon turnover to the private contractor, will be included in an amendment package, as necessary. Should the decision be made by the U.S. Department of Energy, Richland Operations Office (RL), to have DE-AC06-96RL13200, Project Hanford Management Contract (PHMC) (RL 1996), contractors administer the Authorization Basis for Tanks AP-106 and AP-108, this task plan will be changed accordingly and change requests for funding and schedule will be processed.

In addition, the following subjects will be mentioned, but will not be specifically addressed as part of the WFD Authorization Basis amendment.

- The discussion of decontamination and decommissioning of the WFD equipment will be consistent with the level of detail provided in the BIO (FDH 1997). This aspect of the Authorization Basis is being deferred to a TWRS facility Final Safety Analysis Report (FSAR), which is currently under development.

- In accordance with the current Authorization Basis, transfers will require a waste compatibility study and characterization to verify that transferred waste is within the inventory assumptions in the current Authorization Basis or the revised inventory assumptions resulting from the WFD Authorization Basis amendment, as necessary.

- Authorization Bases justifications for Projects W-314 and W-454 will be discussed. 
It is assumed that the Authorization Basis documents in effect during implementation of this task plan will be the BIO (FDH 1997) and the TSRs. If the FSAR replaces the BIO prior to issuance of the WFD Authorization Basis amendment package, then this task plan will be changed accordingly and change requests for funding and schedule will be processed.

\subsection{SAFETY ANALYSIS SCOPE}

Hazard analyses and accident analyses will be performed, documented, and reviewed in accordance with designated procedures. The scope of these analyses will be WFD activities not covered by the current Authorization Basis, with the exception of Projects W-314 and W-454. As shown in Figure 1, Projects W-314 and W-454 are not within the scope of this task plan. Hazard and accident analyses for these projects are performed, documented, and reviewed, as required, based on the appropriate task plans and USQ evaluations.

\subsection{TASK DESCRIPTION AND DELIVERABLES}

\subsection{U.S. DEPARTMENT OF ENERGY ORDERS, STANDARDS, AND PROCEDURES}

The following U.S. Department of Energy (DOE) Orders and Standards apply to the Authorization Basis amendment process:

- DOE Order 5480.21, Unreviewed Safety Questions

- DOE Order 5480.22, Technical Safety Requirements

- DOE Order 5480.23, Nuclear Safety Analysis Reports.

- DOE-STD-1027-92, Hazard Categorization and Accident Analysis Techniques for compliance with DOE Order 5480.23, Nuclear Facility Safety Analysis Reports

- DOE-STD-1104-96, Review and Approval of Nonreactor Nuclear Facility Safety Analysis Reports.

- DOE-STD-3009-94, Preparation Guide for U.S. DOE Nonreactor Nuclear Facility Safety Analysis Reports . 
- DOE-STD-3011-94, Guidance for Preparation of DOE 5480.22 (TSR) and 5480.23 (SAR) Implementation Plans

The following PHMC contractor documents apply to the Authorization Basis amendment process:

- HNF-PRO-244, Engineering Data Transmittal Requirements

- HNF-PRO-317, Engineering Release and Approval Requirements

- $\quad$ HNF-PRO-439, Supporting Document Requirements

- $\quad$ HNF-PRO-440, Engineering Document Change Control Requirements

- HNF-PRO-511, Hazard Classification of Facilities and Segments

- HNF-PRO-514, Risk Guidelines

- $\quad$ HNF-PRO-516, Safety Structures, Systems, and Components

- $\quad$ HNF-PRO-700, Safety Analysis and Technical Safety Requirements

- HNF-PRO-701, Safety Analysis Process - Existing Facility

- HNF-PRO-702, Safety Analysis Process - Facility Change or Modification

- $\quad$ HNF-PRO-703, Safety Analysis Process - New Project

- $\quad$ HNF-IP-0842, Tank Waste Remediation System Administration (LMHC 1997)

- Volume IV, "Engineering," Section 5.4, "Unreviewed Safety Questions"

- Volume IV, "Engineering," Section 5.10, "Authorization Basis Amendments and Annual Updates"

- WHC-SD-MP-SRID-001, High-Level Waste Storage Tank Farms 242-A Evaporator Standards/Requirements Identification Document (S/RID) (Biebesheimer 1996)

- WHC-SD-MP-SRID-002, Westinghouse Hanford Company (WHC) Standards/Requirements Identification Document (S/RID), (Bennett 1996) 


\subsection{SAFETY ANALYSIS ASSUMPTIONS AND PARAMETERS}

DOE Order 5480.23 requires that the assumptions used in the analysis be stated. Key assumptions (i.e., those with an impact on frequency and/or consequence) will be defined for each accident that is evaluated. Assumptions will be stated in sufficient detail to facilitate following the analysis logic without use of references.

Assumptions used in the analyses will be consistent with those in the BIO. The following assumptions are already defined. Others will be defined based on review of the $\mathrm{BIO}$ (FDH 1997) and other documents.

- Material at risk

- The toxicological/radiological source terms will be examined to determine if WFD mission activities (i.e., transfers and waste conditioning) affect the validity of the storage mission source term assumptions. The storage assumption material at risk used in the $\mathrm{BIO}$ (FDH 1997) is documented in WHC-SD-WM-SARR-016, Tank Waste Compositions and Atmospheric Dispersion Coefficients for Use in Safety Analysis Consequence Assessments (Van Keuren 1996) and WHC-SD-WM-SARR-011, Toxic Chemical Considerations for Tank Farm Releases (Van Keuren and Davis 1996). The assumptions from these documents will be compared to inventory information in the WFD Technical Baseline documentation

- Risk Evaluation Guidelines as described in the BIO (FDH 1997)

- Facility Description

- Descriptions of existing TWRS facilities are provided in the BIO (FDH 1997)

- Descriptions of equipment to be installed for WFD activities will come from project documentation as well as WFD Technical Baseline documentation such as HNF-SD-WM-SP-012, Tank Waste Remediation System Operations and Utilization Plan (Kirkbride et al. 1997) and HNF-SD-TWR-TM-001, Technical Baseline Description of High-Level Waste and Low-Activity Waste Feed Mobilization and Delivery (Papp 1997)

- Tank waste compositions will be based on waste compositions defined in Van Keuren (1996) and Van Keuren and Davis (1996) and will 
include non-waste hazardous material inventories (e.g., bulk chemicals used for adjusting $\mathrm{pH}$ ).

\subsection{TASK AND DELIVERABLE DESCRIPTIONS}

The major tasks for the WFD Authorization Basis amendment are described below. Detailed listings of responsibilities and estimated staff loadings for these tasks have been compiled as part of the WFD Technical Basis Review. See the Technical Basis Reviews for Level 1 Logic Activities 620.030, 620.050, 150.B10, 150.B14, 150B16, and 150.B17.

\section{Task 1 - Oversee Scope, Cost, and Schedule}

The primary responsibility for preparation, completion, and implementation of this Authorization Basis Amendment lies with the licensing engineer, who will oversee the scope, cost, and schedule.

\section{Task 2 - Prepare, Review, and Revise Task Plan}

This task plan was prepared to document expectations for deliverables, responsibilities, and schedules. The PHMC subcontractor and sub-subcontractor organizations responsible for actions identified in the plan will review the plan for acceptability. The task plan will be revised upon receipt and review of the engineering baseline documentation which define the equipment and operations associated with the WFD mission. The frequency, and schedule of task plan updates will be a function of the nature and extent of changes which occur to the configuration managed engineering baseline documentation as shown in Figure 2. The first planned update of this task plan will identify specific tasks and refine the resource allocation based on the results of Task.3.

Figure 2. Task Plan Development Flow Chart.

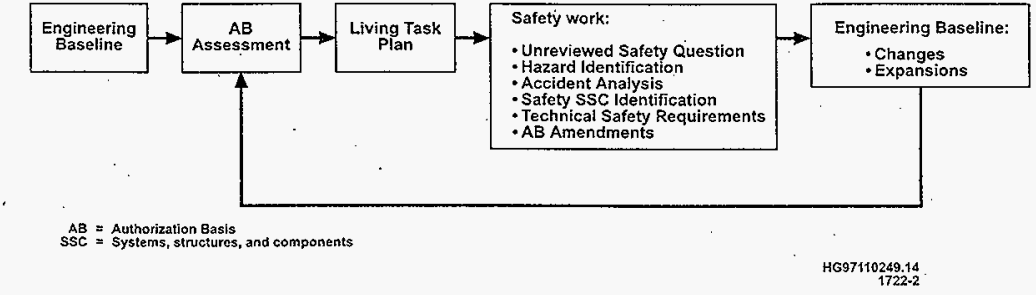




\section{Task 3 - Complete Authorization Basis Assessment for Waste Feed Delivery Activities for Phase 1B}

The first technical activity associated with this task plan is the assessment of the available engineering baseline documents with respect to the current Authorization Basis. This task precedes the performance of USQ evaluations due to the considerable breadth of the WFD mission. The assessment methodology is however, fashioned after the USQ process and is designed to be a preliminary evaluation to determine the mission aspects that may be outside of the current Authorization Basis. For this purpose, the information in the available Technical Baseline documents has been parsed into seven topics as listed in Appendix A. The outcome of the assessment will be used to refine task planning for safety analysis scope, including USQ evaluations, hazards identification, technical analyses, and Authorization Basis amendment package preparation. This information will be used to update this task plan as discussed above (Task 2).

Phase $1 \mathrm{~B}$ WFD construction and operational activities will be evaluated against the Authorization Basis, using the USQ process as a guide. For planning purposes, it has been assumed that USQ screenings on construction activities will produce negative results (i.e., construction activities are enveloped by the current Authorization Basis). This assumption is based on the initial USQ screenings performed for Project W-211 construction activities. It has also been assumed that USQ evaluations of WFD operational activities will conclude that some activities are not enveloped by the Authorization Basis.

Another key assumption is that project and program documentation will provide sufficient detail on Phase 1B WFD activities to allow the USQ screenings to commence. All aspects of the Phase $1 B$ effort are not documented at this time. However, it is assumed that sufficient details are known, particularly on the first tanks to be retrieved, to enable the USQ screenings (and subsequent Authorization Basis modifications) to begin in accordance with the schedule established in this Task Plan. Additional USQ screenings will be performed, as required, when additional technical information becomes available.

If any of the key assumptions described prove to be incorrect, this task plan will be revised accordingly.

As stated previously, it is assumed that the USQ screenings for construction and other activities directly related to the projects cited above will fall within the project scope. However, the results of these screenings for the individual project activities will be factored into the USQ screening(s) of the integrated retrieval and disposal process. 
HNF-1722 Rev 0

\section{Task 4 - Oversee Phase 1B Licensing Strategy}

The initial portion of this activity lies in preparing this task plan, which has already been described in Task 2 above. However, the licensing strategy will continue to evolve as additional project and programmatic information becomes available. The licensing engineer is responsible for reformulating the licensing strategy based on project and program changes.

\section{Task 5 - Safety Analysis and Evaluation Including Development of Safety-Class and Safety-Significant Systems, Structures, and Components and Technical Integration}

The USQ screenings for WFD activities are assumed to result in some positive findings that will require modifications to the Authorization Basis including some new safety analysis. A HAZOP will be performed to determine which accidents are required to be analyzed (or the BIO accidents that need to be reanalyzed). The HAZOP will be performed in accordance with approved procedures. After the new accidents (or BIO accidents that require reanalysis) are identified, frequencies and consequences will be determined. The consequence analysis will be performed in accordance with approved procedures. The assumptions and methodologies used in the BIO (FDH 1997) will be carried forward in this analysis, wherever possible. Safety analysis that has been completed within the scope of the projects (i.e., Projects W-211, W-314, W-454) will be captured within the integrated analysis for the entire WFD process.

After the accident consequences have been determined, the safety-class and safetysignificant systems, structures, and components will be identified (or as an alternative, planned operations may be changed to reduce the consequences to acceptable levels). Safety designation of equipment previously performed under the projects' scope will be captured in this effort.

Technical integration, an important aspect of the strategy for the safety analysis, involves examining the treatment of the major TWRS safety issues to ensure assumptions, approaches, and methodologies are compatible with those used by other TWRS groups working on these same issues. Currently, the four major issues are as follows:

1. Flammable gas

2. Organics

3. Heat generation

4. Criticality.

Other major issues that may arise as the WFD process evolves will also be subject to technical integration. 


\section{Task 6 - Establish Technical Safety Requirements and Administrative Controls}

Based on the results of Task 5, new and/or revised TSRs and Administrative Controls will be identified and documented. Input into this activity will include the "control decision boards" conducted as part of the Task 5 HAZOP activities and the Task 5 hazard and accident analysis results.

\section{Task 7 -Prepare Final Safety Analysis Document}

The results from Tasks 3 through 6 will be used to prepare the Authorization Basis amendment safety analysis document, which will be prepared as an addendum to the BIO (FDH 1997). The safety analysis will be documented in accordance with approved procedures and will include risk evaluation guidelines from the BIO.

The safety analysis will be documented as an addendum to the BIO that follows the format and content guidance of DOE-STD-3009-94 and includes the following:

- Documentation of key assumptions

- Description of changes to the facility

- Additional hazard and accident analyses

- Resolutions to issues identified in USQs

- Potential increased frequency of analyzed accidents

- Potential increased consequences of analyzed accidents

- $\quad$ Potential increased frequency of previously evaluated equipment malfunctions

- Potential increase in consequences of previously evaluated equipment malfunctions

- The need for new or revised TSRs

- New or revised designations of safety-class and safety-significant systems, structures, and components

- TSR derivations, and compensatory measures if needed

- A table mapping the document sections to those in the BIO (FDH 1997). 
NOTE: Should the TWRS FSAR be approved as the Authorization Basis prior to submittal of the WFD amendment package, the amendment package will be submitted as an Engineering Change Notice (ECN) to the FSAR and the table mapping document sections will not be necessary. However, additional work may be required for technical reconciliation since the BIO (FDH 1997) is assumed as the Authorization Basis for this task plan.

\section{Task 8 - Technical Peer Review and Hanford Environmental Dose Overview Panel Review of Safety Analysis Document and Resolution of Comments}

Technical peer reviews and Hanford Environmental Dose Overview Panel reviews will be performed in accordance with approved procedures. The person designated for each area of expertise reviews the appropriateness of TSR derivations and designations of safety-class and safety-significant systems, structures, and components related to the assigned area of expertise.

Task 9 - Mark up Technical Safety Requirements and Prepare Engineering ChangeNotice

The TSR documentation developed in Task 6 will be used to revise the TSR document, HNF-SD-WM-TSR-006, Tank Waste Remediation System Technical Safety Requirements (Noorani 1997), and prepare ECN page changes. (This effort will include necessary revisions to the Administrative Controls and TSR Bases.) A table will be prepared to summarize the changes in the TSRs (i.e., a table that lists the existing controls that are being changed, and how they are being changed). This table will be used in the Standards/Requirements Identification Document (S/RID) evaluation and as needed for presentations to Lockheed Martin Hanford Corporation (LMHC), Fluor Daniel Hanford, Inc. (FDH) and RL.

\section{Task 10 - Prepare Engineering Change Notice to add Safety Analysis Document as Addendum to Basis of Interim Operations}

The safety analysis documented and reviewed in Tasks 7 and 8 will be used to prepare an ECN to add the safety analysis document to the BIO (FDH 1997) as an addendum. A table will be prepared to summarize the changes in the BIO and the effect of the changes. This table will be used in the S/RID evaluation and as needed for presentations to $\mathrm{LMHC}, \mathrm{FDH}$, and RL.

\section{Task 11 - Revise Standards/Requirements Identification Document if Necessary}

Based on the safety analysis and TSRs documented and reviewed in Tasks 7 and 8 , and the tables summarizing the TSR and BIO (FDH 1997) changes from Tasks 9 and 10, the need for revising the S/RID will be evaluated. If a revision is necessary (which would 
only occur if an addition to the S/RID is required), an ECN and corresponding page changes will be prepared.

\section{Task 12 - Assemble Authorization Basis Amendment Package}

The Authorization Basis Amendment Package will contain the following:

1. All WFD-related USQ documentation (except W-314 and W-454)

2. Safety analysis document (including documentation of Technical Peer Reviews and Hanford Environmental Dose Overview Panel review, and Engineering Data Transmittal)

3. ECN to add safety analysis document as addendum to the BIO (FDH 1997) (or FSAR, if approved)

4. Markup of TSRs (and/or page changes) and ECN

5. Compensatory measures, if applicable

6. Amendment Implementation Plan (which will include any considerations for the in-place Compliance Implementation Plan)

7. Markup of S/RID and corresponding ECN (if applicable)

8. Update of the Safety Equipment List

9. Revisions to Van Keuren (1996) and Van Keuren and Davis (1996), if required. Any changes to these documents will be evaluated for impact on the current Authorization Basis.

\section{Task 13 - Develop Amendment Implementation Plan}

Based on the results of the safety analysis documented and reviewed in Tasks 7 and 8 , an Amendment Implementation Plan will be developed. This document will describe all necessary actions to completely implement the Authorization Basis amendment (e.g., implementation of compensatory measures, implementation of new or revised TSRs, changes to the Authorization Basis document list, changes to the Facility Compliance Matrix, changes to procedures, training associated with implementation of new controls and procedures, etc.). The document will also consider potential changes to the in-place Compliance Implementation Plan for the BIO (FDH 1997). 
HNF-1722 Rev 0

Based on the results of the previous tasks, the Amendment Implementation Plan will be prepared in accordance with HNF-IP-0842, Volume IV, "Engineering," Section 5.10, "Authorization Basis Amendments and Annual Updates" (LMHC 1997). The plan will include a schedule and responsibilities for completion of implementation and the criteria to be used to verify the implementation.

\section{Task 14 - Functional Review of Authorization Basis Amendment Package and Resolution of Comments}

Functional reviews of the amendment package will be performed. Operations \& Projects Safety Support will coordinate the functional reviews and resolution of comments.

Task 15 - Submit Authorization Basis Amendment Package to Fluor Daniel Hanford, Inc. and Facilitate Transmittal to U.S. Department of Energy, Richland Operations Office

Operations \& Projects Safety Support will prepare the Authorization Basis amendment package transmittal letter to $\mathrm{FDH}$. The letter will include specific requests for FDH to communicate to RL (1) that a safety evaluation report is needed to allow completion and implementation of the Authorization Basis amendment, (2) when the safety evaluation report is needed and why, and (3) the identity of a singie point of contact for comments and communications from RL.

FDH will review the package and comments will be resolved accordingly. When comments are resolved, FDH. will submit the Authorization Basis Amendment Package to RL.

Task 16 - U.S. Department of Energy, Richland Operations Office Review and Approval of Authorization Basis Amendment Package

RL will perform the Tier II/Tier III review of the package. Comments will be resolved accordingly, and RL will issue the safety evaluation report.

\section{Task 17 - Issue Revised Safety Documentation}

The approved versions of the following safety documentation will be formally issued in accordance with appropriate document control procedures:

1. Safety analysis document (with safety evaluation report included)

2. BIO (FDH 1997) (or FSAR, if approved) Addendum (via ECN)

3. Revised TSRs (via ECN) 
4. Safety Basis and/or Authorization Basis Document Lists

5. Amendment Implementation Plan

6. Procedures.

Task 18 - Complete All Action Items, Verify Implementation, and Notify U.S. Department of Energy, Richland Operations Office

All action items from the Amendment Implementation Plan will be completed and verified. A letter will be prepared to notify FDH of full implementation. The letter will request $\mathrm{FDH}$ to notify $\mathrm{RL}$ of full implementation of the Authorization Basis amendment. FDH will then notify RI accordingly.

\subsection{RESPONSIBILITIES AND STAFFING REQUIREMENTS}

Detailed listings of responsibilities and estimated staff loadings have been compiled as part of the WFD Technical Basis Review. See the Technical Basis Reviews for Level 1 Logic Activities 620.030, 620.050, 150.B10, 150.B14, 150.B16, and 150.B17.

\subsection{SCHEDULE}

Table 1. Schedule for Waste Feed Delivery Authorization Basis Amendment. (2 Sheets)

\begin{tabular}{|c|l|c|c|}
\hline $\begin{array}{c}\text { Task } \\
\text { Number }\end{array}$ & \multicolumn{1}{|c|}{ Task } & \multicolumn{1}{c|}{ Schedule } & Duration \\
\hline 1 & $\begin{array}{l}\text { Oversee scope, cost, and schedule of } \\
\text { Authorization Basis amendment }\end{array}$ & Throughout task & \\
\hline 2 & Prepare and deliver initial Task Plan & $7 / 14 / 97-1 / 12 / 98$ & $6 \mathrm{mos}$ \\
\cline { 2 - 4 } & Prepare and deliver first Task Plan update & $1 / 12 / 98-2 / 27 / 98$ & 6 wks \\
\hline & $\begin{array}{l}\text { Prepare and deliver subsequent Task Plan } \\
\text { updates (as required) }\end{array}$ & $2 / 27 / 98-3 / 18 / 99$ & 14 mos \\
\hline 3 & $\begin{array}{l}\text { Complete Authorization Basis Assessments for } \\
\text { Waste Feed Delivery Activities for Phase 1B }\end{array}$ & $10 / 1 / 97-12 / 19 / 97 \mathrm{~A}$ & 11 wks \\
\hline 4 & Oversee licensing strategy for Phase 1B & Throughout task & \\
\hline 5 & Safety analysis and evaluation & $10 / 1 / 97-7 / 8 / 98$ & 8 mos \\
\hline
\end{tabular}


Table 1. Schedule for Waste Feed Delivery Authorization Basis Amendment. (2 Sheets)

\begin{tabular}{|c|c|c|c|}
\hline $\begin{array}{c}\text { Task } \\
\text { Number }\end{array}$ & Task & Schedule & Duration \\
\hline 6 & $\begin{array}{l}\text { Identify and document new and/or revised } \\
\text { controls and compensatory measures, if } \\
\text { necessary, based on results of Task } 5\end{array}$ & $3 / 16 / 98-9 / 15 / 98$ & 6 mos \\
\hline 7 & $\begin{array}{l}\text { Prepare final safety analysis document as an } \\
\text { addendum to the BIO (FDH 1997) based on } \\
\text { results of all previous tasks }\end{array}$ & $9 / 16 / 98-10 / 27 / 98$ & 6 ẉks \\
\hline \multirow[t]{2}{*}{8} & $\begin{array}{l}\text { Technical peer review and HEDOP review of } \\
\text { safety analysis document. }\end{array}$ & $10 / 28 / 98-11 / 17 / 98$ & 3 wks \\
\hline & $\begin{array}{l}\text { MILESTONE } \\
\text { Resolve comments from technical peer review } \\
\text { and HEDOP review }\end{array}$ & $11 / 18 / 98-12 / 3 / 98$ & 2 wks \\
\hline $9-12$ & $\begin{array}{l}\text { Prepare Authorization Basis Amendment } \\
\text { Package }\end{array}$ & $9 / 16 / 98-10 / 27 / 98$ & $6 \mathrm{wks}$ \\
\hline 13 & Develop amendment implementation plan & $12 / 4 / 98-12 / 28 / 98$ & $24 d$ \\
\hline 14 & $\begin{array}{l}\text { Functional review of Authorization Basis } \\
\text { Amendment Package }\end{array}$ & $1 / 6 / 99-2 / 2 / 99$ & 4 wks \\
\hline $14-15$ & $\begin{array}{l}\text { MILESTONE } \\
\text { Resolve functional review comments and issue } \\
\text { Authorization Basis Amendment Package to } \\
\text { DOE }\end{array}$ & $2 / 3 / 99-2 / 24 / 99$ & 3 wks \\
\hline \multirow[t]{5}{*}{16} & $\begin{array}{l}\text { DOE review of Authorization Basis Amendment } \\
\text { Package (Tier II review) }\end{array}$ & $2 / 25 / 99-3 / 25 / 99$ & 4 wks \\
\hline & Resolve DOE Tier II comments & $3 / 26 / 99-4 / 23 / 99$ & $4 \mathrm{wks}$ \\
\hline & $\begin{array}{l}\text { DOE Tier III review of Authorization Basis } \\
\text { Amendment Package }\end{array}$ & $4 / 26 / 99-5 / 14 / 99$ & $3 \mathrm{wks}$ \\
\hline & Resolve DOE Tier III comments & $5 / 17 / 99-6 / 4 / 99$ & 3 wks \\
\hline & DOE issue SER & $6 / 7 / 99-6 / 11 / 99$ & 1 wk \\
\hline 17 & Issue revised safety documentation & $6 / 14 / 99-6 / 21 / 99$ & $1 \mathrm{wk}$ \\
\hline 18 & Implementation & $6 / 14 / 99-8 / 6 / 99$ & 8 wks \\
\hline
\end{tabular}

FDH, 1997, Tank Waste Remediation System Basis for Interim Operation, HNF-SD-WM-BIO-001, Rev. 0, Fluor Daniel Hanford, inc., Richland, Washington. DOE $=$ U.S. Department of Energy.

HEDOP $=$ Hanford Environmental Dose Overview Panel. SER $=$ Safety Evaluation Report. 
HNF-1722 Rev 0

\subsection{TASK CONTROL}

The task will be managed with the following:

- Operations and Project Safety Support internal weekly status meetings

- Monthly Project Review status meetings with LMHC, FDH, and RL

- Project-specific status and reporting requirements.

\subsection{REFERENCES}

\section{Department of Energy Orders}

DOE Order 5480.21, Unreviewed Safety Questions, U.S. Department of Energy, Washington, D.C.

DOE Order 5480.22, Technical Safety Requirements, U.S. Department of Energy, Washington, D.C.

DOE Order 5480.23, Nuclear Safety Analysis Reports, U.S. Department of Energy, Washington, D.C.

\section{Department of Energy Standards}

DOE-STD-1027-92, Hazard Categorization and Accident Analysis.Techniques for Compliance with DOE Order 5480.23, Nuclear Safety Analysis Reports, U.S. Department of Energy, Washington, D.C.

DOE-STD-1104-96, Review and Approval of Nonreactor Nuclear Facility Safety Analysis Reports, U.S. Department of Energy, Washington, D.C.

DOE-STD-3009-94, Preparation Guide for U.S. DOE Nonreactor Nuclear Facility Safety Analysis Reports, U.S. Department of Energy, Washington, D.C.

DOE-STD-3011-94, Guidance for Preparation of DOE 5480.22 (TSR) and 5480.23 (SAR) Implementation Plans, U.S. Department of Energy, Washington, D.C. 


\section{HNF Procedures}

HNF-PRO-244, Engineering Data Transmittal Requirements, Fluor Daniel Hanford, Inc., Richland, Washington.

HNF-PRO-317, Engineering Release and Approval Requirements, Fluor Daniel Hanford, Inc., Richland, Washington.

HNF-PRO-439, Supporting Document Requirements, Fluor Daniel Hanford, Inc., Richland, Washington.

HNF-PRO-440, Engineering Document Change Control Requirements, Fluor Daniel Hanford, Inc., Richland, Washington.

HNF-PRO-511, Hazard Classification of Facilities and Segments, Fluor Daniel Hanford, Inc., Richland, Washington.

HNF-PRO-514, Risk Guidelines, Fluor Daniel Hanford, Inc., Richland, Washington.

HNF-PRO-516, Safety Structures, Systems, and Components, Fluor Daniel Hanford, Inc., Richland, Washington.

HNF-PRO-700, Safety Analysis and Technical Safety Requirements, Fluor Daniel Hanford, Inc., Richland, Washington.

HNF-PRO-701, Safety Analysis Process-Existing Facility, Fluor Daniel Hanford, Inc., Richland, Washington.

HNF-PRO-702, Safety Analysis Process-Facility Change or Modification, Fluor Daniel Hanford, Inc., Richland, Washington.

HNF-PRO-703, Safety Analysis Process-New Project, Fluor Daniel Hanford, Inc., Richland, Washington.

\section{Documents}

Bennett, G. L., 1996, Westinghouse Hanford Company (WHC) Standards/Requirements Identification Document (S/RID), WHC-SD-MP-SRID-002, Rev. 0, Westinghouse Hanford Company, Richland, Washington.

Biebesheimer, E., 1996, High-Level Waste Storage Tank Farms 242-A Evaporator Standards/Requirements Identification Document (S/RID), WHC-SD-MP-SRID-001,

- Rev. 1, Westinghouse Hanford Company, Richland, Washington. 
FDH, 1997, Tank Waste Remediation System Basis for Interim Operation, HNF-SD-WM-BIO-001, Rev. 0, Fluor Daniel Hanford Inc., Richland, Washington.

Kirkbride, R.A., G. K. Allen, P. J. Certa, A. F. Manuel, R. M. Orme, L. W. Shelton, E. J. Slaathaug, R. S. Wittman, and G. T. MacLean, and D. L. Penwell (SESC), 1997, Tank Waste Remediation System Operation and Utilization Plan, HNF-SD-WM-SP012, Rev. 0, Volumes I and II, prepared by Numatec Hanford Corporation for Fluor Daniel Hanford, Inc., Richland, Washington.

LMHC, 1997, TWRS Administration, HNF-IP-0842, Fluor Daniel Hanford, Inc., Richland, Washington.

Noorani, Y. G., 1997, Tank Waste Remediation System Technical Safety Requirements, HNF-SD-WM-TSR-006, Rev. 0, prepared by DE\&S Hanford, Inc., for Fluor Daniel Hanford, Inc., Richland, Washington.

Papp, I. G., 1997, Technical Baseline Description of High-Level Waste and Low-Activity Waste Feed Mobilization and Delivery, HNF-SD-TWR-TM-001, Rev. 0, prepared by Numatec Hanford Corporation for Fluor Daniel Hanford Inc., Richland, Washington.

RL, 1996, Project Hanford Management Contract (PHMC), DE-AC06-96RL13200, U.S. Department of Energy, Richland Operations Office, Richland, Washington.

Van Keuren, J. C., 1996, Tank Waste Compositions and Atmospheric Dispersion Coefficients for Use in Safety Analysis Consequence Assessments, WHC-SD-WM-SARR-016, Rev. 2, Westinghouse Hanford Company, Richland, Washington.

Van Keuren, J. C., and J. S. Davis, 1996, Toxic Chemical Considerations for Tank Farm Releases, WHC-SD-WM-SARR-011, Rev. 2, Westinghouse Hanford Company, Richland, Washington. 
HNF-1722 Rev 0

This page intentionally left blank. 
HNF-1722 Rev 0

APPENDIX A

WASTE FEED DELIVERY AUTHORIZATION BASIS ASSESSMENT

LICENSING STRATEGY EVALUATION TOPICS

TWRS RETRIEVAL AUTHORIZATION BASIS

AMENDMENT TASK PLAN 
HNF-1722 Rev 0

This page intentionally left blank. 


\section{APPENDIX A \\ WASTE FEED DELIVERY AUTHORIZATION BASIS ASSESSMENT \\ LICENSING STRATEGY EVALUATION TOPICS \\ TWRS RETRIEVAL AUTHORIZATION BASIS \\ AMENDMENT TASK PLAN}

A. Waste Mobilization (source tanks)

Sludge/solids mobilization (mixer pumps)

Sludge/solids mobilization (sluicer)

B. Waste Transfer (source to feed staging tanks)

Waste conditioning (dilution/pH adjustment)

Transfer to staging tanks

C. Interim Storage (source and feed delivery tanks)

Supernatant (minimal solids) consolidation and storage

Sludge/solids consolidation and storage

Waste return feed storage (return from treatment plant)

Return and interim storage of spent resin

D. Waste Separation (source tanks)

Caustic sludge washing

Water-based sludge washing .

E. Waste Batch Transfer (feed staging to private contractor tanks)

Waste sampling

Waste feed adjustments ("shimming")

Transfer to private contractor tanks

F. Immobilized Waste Transfer and Storage (storage/disposal)

Immobilized low-activity waste transport and storage/disposal (W-465, W-520)

Immobilized high-level waste transport and storage/disposal (W-464) 
HNF-1722 Rev 0

\section{G. Miscellaneous WFD Activities}

Maintenance of critical equipment

Removal and packaging of long-length equipment

Others - to be identified 
HNF-1722 Rev 0

\section{APPENDIX B \\ GUIDANCE AND REQUIREMENTS TO DELIVERABLES \\ CROSSWALK}

TWRS RETRIEVAL AUTHORIZATION BASIS

AMENDMENT TASK PLAN 


\section{HNF-1722 Rev 0}

$\therefore$

This page intentionally left blank. 
Table B-1. Guidance and Requirements to Deliverables Crosswalk - TWRS Retrieval Authorization Basis Amendment Task Plan.

\begin{tabular}{|c|c|c|}
\hline \multirow{2}{*}{$\begin{array}{l}\text { Guidance or Requirement } \\
\text { Al DOE Letter to H. J Hatch, FDH, from W J Taylor, } \\
\text { DOE, dated August } 8,1997, \# 9757162 \mathrm{~A}(36 \mathrm{ITEM} \\
\text { CHECKIIST) }\end{array}$} & \multirow{2}{*}{ Status } & \multirow[t]{2}{*}{ Implementing Location } \\
\hline & & \\
\hline $\begin{array}{l}\text { 32. Environmental permits and safety authorization bases } \\
\text { are in place as required for authorization-to-proceed } \\
\text { decision. }\end{array}$ & $\mathrm{I}$ & Entire Document \\
\hline $\begin{array}{l}\text { B. } 1 \text { DOE Order } 430.1 \text {, Good Practice Guide, GPG } \\
\text { FM-002 }\end{array}$ & & \\
\hline 2.3.6 Environment, Safety and Health Criteria & $\mathrm{I}$ & Entire Document \\
\hline 2.4.6 Environment, Safety and Health Criteria & $\therefore$ & \\
\hline 1. Safety Analysis & $\mathrm{I}$ & Entire Document \\
\hline 4. Permits, Licenses, and Regulatory Approval & $\mathrm{I}$ & $\begin{array}{l}\text { Section } 3.3 \text {, Task } 16 \text {; Section } 5.0 \\
\text { Task } 16\end{array}$ \\
\hline 2.5.6 Environment, Safety and Health Criteria & . & \\
\hline 1. Safety Analysis & I & Entire Document \\
\hline C.1 Interface Control Docuinents & \% & Wy 2 - \\
\hline 3. Radioactive Solid Wastes & . & \\
\hline $\begin{array}{l}\text { 2. Negotiate any necessary modification to Hanford Site } \\
\text { permits with the regulator(s). }\end{array}$ & $\bar{I}$ & $\begin{array}{l}\text { If the Authorization Basis is } \\
\text { impacted, then an amendment will } \\
\text { be submitted. }\end{array}$ \\
\hline 4. Dangerous Wastes & . & \\
\hline $\begin{array}{l}\text { 1. Not accept non-radioactive, dangerous waste from the } \\
\text { Contractor. }\end{array}$ & I & $\begin{array}{l}\text { If the Authorization Basis is } \\
\text { impacted, then an amendment will } \\
\text { be submitted. }\end{array}$ \\
\hline 5. Non-Radioactive, Non-Dangerous Liquid Effluents & $\mathrm{I}$ & $\begin{array}{l}\text { If the Authorization Basis is } \\
\text { impacted, then an amendment will } \\
\text { be submitted. }\end{array}$ \\
\hline 6. Radioactive, Dangerous Liquid Effluents & $\mathrm{I}$ & $\begin{array}{l}\text { If the Authorization Basis is } \\
\text { impacted, then an amendment will } \\
\text { be submitted. }\end{array}$ \\
\hline 22. Air Emissions - Permits & $\bar{I}$ & $\begin{array}{l}\text { If the Authorization Basis is } \\
\text { impacted, then an amendment will } \\
\text { be submitted. }\end{array}$ \\
\hline $\begin{array}{l}\text { D.1 Detailed Instructions for As } \\
\text { Appendix C, November 14, } 199 \text { ? }\end{array}$ & & \\
\hline
\end{tabular}




\section{DISTRIBUTION SHEET}

\begin{tabular}{|c|c|c|c|c|c|}
\hline \multirow{2}{*}{$\begin{array}{l}\text { To } \\
\text { Distribution }\end{array}$} & \multirow{2}{*}{\multicolumn{3}{|c|}{$\begin{array}{l}\text { From } \\
\text { TWRS Configuration Management }\end{array}$}} & \multicolumn{2}{|c|}{ Page 1 of 2} \\
\hline & & & & \multicolumn{2}{|l|}{ Date $1 / 8 / 98$} \\
\hline \multirow{2}{*}{\multicolumn{4}{|c|}{$\begin{array}{l}\text { Project Title/Work Order } \\
\text { Tank Waste Remediation }\end{array}$}} & \multicolumn{2}{|c|}{ EDT No. 622842} \\
\hline & & & & \multicolumn{2}{|l|}{ ECN No. } \\
\hline Name & MSIN & $\begin{array}{c}\text { Text } \\
\text { With All } \\
\text { Attach. }\end{array}$ & Text Only & $\begin{array}{l}\text { Attach./ } \\
\text { Appendix } \\
\text { Only }\end{array}$ & $\begin{array}{l}\text { EDT/ECN } \\
\text { Only }\end{array}$ \\
\hline
\end{tabular}

J. N. Alibert

$P$. R. Angelier

D. G. Baide

N. F. Barilo, Jr.

E. Biebesheimer

T. W. Bohan

J. F. Bores

H. L. Boston

M. C. Brady

K. C. Burgard

S. M. Byers

L. M. CaIderon

P. J. Certa

A. F. Choho

J. S. Davis

M. P. Delozier

B. G. ErTandson

J. S. Garfield

K. A. Gasper

G. W. Gault

T. S. Geer

T. G. Goetz

W. H. Grams

0. A. Halvorson

D. M. Hammond

J. P. Harris III

J. L. Homan

J. 0. Honeyman

T. M. Horner

M. G. Hunn

M. N. Islam

K. N. Jordan

R. A. Kirkbride

J. F. Kristofzski

C. E. Leach

R. P. Marsha11, Jr.

E. E. Mayer

K. H. Morris

P. Mouette

R. J. Murkowski

M. J. O'Neill

I. G. Papp

M. A. Payne

L. D. Pennington

R. W. Powell.
S2-48

S7-82

S5-05

R3-01

R2-82

S5-04

G3-21

G3-21

R1-43

H6-37

S1-57

R3-01

H5-61

H6-35

RT-49

R2-58

R1-51

H5- 49

H6-37

R1-44

R1-43

R1-49

R1-49

G3-21

R1-44

R1-49

T4-07

G3-21

R2-82

R1 -49

S5-12

G3-21

H5-27

R2-12

RI-49

H5-61

R2-36

Rl-49

RT-49

H6-37

G3-21

H5-49

R2-58

S7-21

H5-03

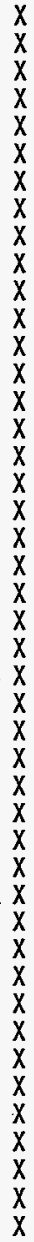




\section{DISTRIBUTION SHEET}

\begin{tabular}{|c|c|c|c|c|c|}
\hline \multirow{2}{*}{$\begin{array}{l}\text { To } \\
\text { Distribution }\end{array}$} & \multirow{2}{*}{\multicolumn{3}{|c|}{$\begin{array}{l}\text { From } \\
\text { TWRS Configuration Management }\end{array}$}} & \multicolumn{2}{|l|}{ Page 2 of 2} \\
\hline & & & & \multicolumn{2}{|c|}{ Date $1 / 8 / 98$} \\
\hline \multirow{2}{*}{\multicolumn{4}{|c|}{$\begin{array}{l}\text { Project Title/Work Order } \\
\text { Tank Waste Remediation System (HNF-1722) }\end{array}$}} & \multicolumn{2}{|c|}{ EDT No. 622842} \\
\hline & & & & \multicolumn{2}{|l|}{ ECN No. } \\
\hline Name & MSIN & $\begin{array}{l}\text { Text } \\
\text { With All } \\
\text { Attach. }\end{array}$ & Text Only & $\begin{array}{l}\text { Attach./ } \\
\text { Appendix } \\
\text { Only }\end{array}$ & $\begin{array}{l}\text { EDT/ECN } \\
\text { Only }\end{array}$ \\
\hline
\end{tabular}

R. E. Raymond

R. P. Raven

D. W. Reberger

C. A. Rieck

S. H. Rifaey

B. Root

W. W. Rutherford

P. S. Schaus

R. D. Smith

R. G. Stickney

G. R. Tardiff

M. S. Tiffany

W. T. Thompson

R. L. Treat

J. E. VanBeek

J. M. Vann

K. A. White

J. H. Wicks, Jr.

R. D. Wojtasek

$\begin{array}{ll}R 2-38 & x \\ R 1-51 & x \\ S 5-13 & x \\ S 2-48 & x \\ R 1-56 & x \\ G 3-21 & x \\ R 3-25 & x \\ H 5-03 & x \\ R I-49 & x \\ R 1-49 & x \\ S 5-05 & x \\ R 1-49 & x \\ G 5-21 & x \\ H 5-03 & x \\ S 2-48 & x \\ H 6-37 & x \\ S 5-13 & x \\ H 7-07 & x \\ G 3-21 & x\end{array}$

